\title{
Karakteristik Sifat Kuantitatif dan Kualitatif Kambing Lokal di Pulau Moa, Provinsi Maluku
}

\section{(Characteristics of Quantitative and Qualitative Traits of Local Goat in Moa Island, Maluku Province)}

Nurfaizin, Matitaputty PR

Balai Pengkajian Teknologi Pertanian Maluku, Jl. Chr. Soplanit Rumah Tiga Ambon nurfaizinspt@gmail.com

\begin{abstract}
Barat Daya Maluku District consist of many islands and has specific climate and agroecosystem compare with other regions. The capital of the district located in Tiakur precisely on Moa Island which has dry land agroecosystem and rainfall less than $1,000 \mathrm{~mm} / \mathrm{year}$. These conditions affected the poor nutritional content of grassfield even though the local goats are well adapted to growth. Therefore to determine potential production of the local goats on the Moa Island, it is necessary to study the the characteristics of quantitative and qualitative phenotype. The study used 23 male and 25 female lamb, and 11 male and 23 does, respectively. The quantitative and qualitative data were analyzed by descriptive and to determine the relationship of morphometric with body weight analyzed by correlations. The results of local goats quantitative characteristics on Moa Island has variations such as body weight and morphometric. The coat color of goats are varied as well as flat face form, shape of horns, ears, and backs. The goat morphometric specially chest diameter has correlation with body weight of local goat on Moa Island.
\end{abstract}

Key Word: Local Goats, Characteristic, Quantitative and Qualitative Trait

\begin{abstract}
ABSTRAK
Kabupaten Maluku Barat Daya memiliki banyak pulau serta iklim dan agroekosistem spesifik jika dibandingkan dengan daerah lain. Ibu kota kabupaten berada di Tiakur tepatnya di Pulau Moa yang memiliki agroekosistem lahan kering dengan curah hujan kurang dari $1.000 \mathrm{~mm} /$ tahun. Keadaan tersebut berpengaruh terhadap rendahnya kandungan nutrisi rumput di padang penggembalaan meskipun kambing lokal mampu beradaptasi dan berkembang. Oleh karena itu, untuk mengetahui potensi kambing lokal di Pulau Moa perlu dilakukan kajian karakteristik fenotipe berupa sifat kualitatif dan kuantitatif. Materi penelitian adalah kambing lokal yang terdiri dari 23 ekor anak kambing jantan dan 25 ekor betina, serta 11 ekor kambing dewasa jantan dan 23 ekor betina. Data sifat kuantitatif dan kualitatif dianalisis secara deskriptif dan untuk mengetahui hubungan ukuran tubuh dengan bobot badan dianalisis secara korelasi. Hasil karakteristik kambing lokal di Pulau Moa memiliki sifat kuantitatif berupa bobot badan dan sejumlah ukuran tubuh yang mencerminkan variasi. Karakteristik kualitatif warna bulu bervariasi, bentuk muka datar, bentuk tanduk, telinga dan punggung bervariasi. Ukuran tubuh kambing terutama lingkar dada memiliki hubungan erat terhadap bobot badan kambing lokal di Pulau Moa.
\end{abstract}

Kata Kunci: Kambing Lokal, Karakteristik, Sifat Kuantitatif dan Kualitatif

\section{PENDAHULUAN}

Kabupaten Maluku Barat Daya (MBD) merupakan kabupaten yang memiliki banyak pulau serta memiliki iklim dan agroekosistem yang spesifik dibandingkan dengan daerah lain. Ibu kota Kabupaten MBD berada di Tiakur tepatnya di Pulau Moa. Keadaan topografi Pulau Moa berbukit-bukit karang rendah. Deretan Barat terdapat dua gunung yaitu 
Kogotea dan Limar, sedangkan bagian timur terdapat dua puncak masing-masing Kuli (Kerbau) dan Watumermora (Thenu 2013). Penyebaran ternak berdasarkan geografis Pulau Moa yaitu Kerbau Moa ditemui di kaki gunung dimana terdapat air untuk berkubang sedangkan ternak kambing dapat ditemukan di hampir semua kondisi agroekosistem marginal, sulit air, kering dan tepi pantai (Nurfaizin et al. 2016). Populasi ternak kambing di Kabupaten MBD pada tahun 2014 berjumlah 40.601 ekor sementara di Pulau Moa terdapat kambing sejumlah 5.420 ekor. Jumlah tersebut memberikan proporsi sebagai populasi ternak terbesar kedua setelah kerbau di Pulau Moa (BPS 2016).

Pulau Moa memiliki agroekosistem lahan kering dengan curah hujan kurang dari $1.000 \mathrm{~mm} /$ tahun. Keadaan demikian berpengaruh terhadap makhluk hidup di sekitar wilayah. Struktur komposisi padang penggembalaan di Pulau Moa yaitu ditumbuhi rumput kusu-kusu serei, rumput sasak, rumput lapangan, rumput merak dan dijumpai beberapa jenis rumput liar lainnya yang agak sulit untuk dideterminasi karena hijauan tersebut belum lazim. Rata-rata kandungan nutrisi rumput di padang penggembalaan tergolong rendah yakni protein kasar 4,04\% kadar air 12,37\% dan serat kasar 45,15\% (Eoh 2014). Meskipun demikian kambing lokal di Pulau Moa mampu beradaptasi dan berkembang pada lingkungan tersebut.

Letak geografis Pulau Moa berdekatan dengan Pulau Lakor sehingga memiliki kesamaan wilayah pembangunan Kabupaten MBD yaitu gugus Pulau Lemola yang terdiri dari Pulau Leti, Moa, Lakor (Thenu 2013). Keadaan tersebut memungkinkan frekuensi transportasi dua arah sehingga kambing lokal di Pulau Moa diduga merupakan bagian dari kambing Lakor meskipun informasi mengenai sumber daya genetik khususnya kambing lokal di MBD masih minim. Secara umum, kambing lokal memiliki beberapa keunggulan dibandingkan dengan jenis kambing lain yaitu mampu beradaptasi dengan baik pada kondisi pakan yang berkualitas rendah, memiliki ketahanan yang cukup tinggi pada tekanan iklim setempat, merupakan sumber daya genetik spesifik, serta berperan dalam menyediakan keragaman pangan pertanian dan budaya bagi masyarakat (Ilham 2012).

Agar ternak lokal dapat dimanfaatkan harus diketahui potensinya sehingga perlu dilakukan kajian karakteristik fenotipe berupa sifat kualitatif dan kuantitatif dari ternak. Tujuan dari karakterisasi adalah untuk mendapatkan data sifat atau deskripsi morfologi dari ternak kambing yang bertujuan untuk membedakan fenotipe dan seberapa besar keragaman genetik yang dimiliki pada wilayah tersebut (Adiati \& Priyanto 2011). Sifat kualitatif merupakan suatu sifat yang dapat diamati atau tampak dan dideskripsikan secara langsung, sehingga masing-masing individu dapat diklasifikasikan ke dalam beberapa kelompok, berdasarkan warna bulu, bentuk tanduk dan bentuk telinga. Sifat kuantitatif merupakan sifat yang tidak dapat dikelompokkan secara langsung melainkan harus dilakukan dengan cara penimbangan dan pengukuran pada tubuh ternak, seperti bobot badan (Wahyuni et al. 2016).

Pengkajian ini bertujuan untuk mengetahui karakteristik fenotipe sifat kualitatif khususnya warna bulu, bentuk muka, telinga, tanduk dan punggung sekaligus sifat kuantitatif bagian tubuh serta bobot badan sekaligus hubungannya pada kambing lokal yang terdapat di Pulau Moa Kabupaten MBD.

\section{MATERI DAN METODE}

Pengkajian dilakukan pada bulan April-Desember 2016 di Kabupaten MBD dengan lokasi sampel di Pulau Moa, Kecamatan Moa, Desa Moain Dusun Moain dan Pilam. Materi penelitian adalah kambing lokal yang terdiri dari anak kambing umur kurang dari satu tahun, 23 ekor jantan dan 25 ekor betina, 11 ekor jantan umur dewasa 1-3 tahun dan 23 ekor betina, pita ukur untuk mengukur panjang ukuran tubuh, timbangan gantung untuk 
mengetahui bobot badan ternak, pena dan buku catatan untuk mencatat data penelitian. Penentuan umur ternak kambing diketahui dengan melihat jumlah kondisi gigi seri (Sulastri \& Sumadi 2005).

Data diperoleh dengan cara mengumpulkan data langsung di lapangan dan wawancara dengan peternak. Pengamatan karakteristik fenotipe kuantitatif yang diamati adalah penimbangan bobot badan ternak dan ukuran tubuh dari berbagai pengelompokan umur. Sifat kuantitatif ukuran tubuh kambing diperoleh dengan cara melakukan pengukuran baik dengan cara penimbangan ataupun pengukuran dengan menggunakan alat ukur sehingga hasilnya berupa angka (Gambar 1).

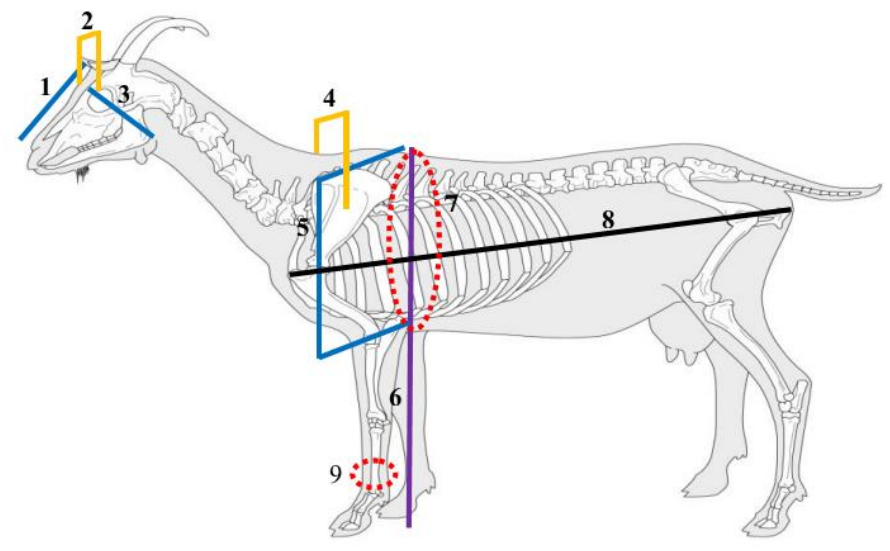

1: Panjang kepala; 2: Lebar kepala; 3: Tinggi kepala; 4: Lebar dada; 5: Dalam dada; 6: Tinggi pundak; 7: Lingkar dada; 8: Panjang badan; 9: Lingkar canon kaki kiri depan

Sumber: Ilham (2012)

Gambar 1. Ukuran tubuh yang diamati

Pengamatan sifat kualitatif berdasarkan sifat luar yang tampak antara lain warna bulu, bentuk garis muka, tanduk, punggung dan tipe telinga. Sifat kualitatif sebaran pola warna pada seluruh bagian tubuh yang dibagi ke dalam warna dasar dominan kemudian dikelompokkan ke dalam tiga kelompok warna dasar utama yaitu putih, hitam dan cokelat serta berbagai kombinasi dari masing-masing ketiga warna dasar dominan tersebut.

Data penelitian karakteristik fenotipe kuantitatif yang diperoleh dianalisis secara deskriptif dengan menghitung nilai rata-rata dan standar deviasi pada setiap sifat yang diamati sedangkan data kualitatif dianalisis berdasarkan distribusi frekuensi. Analisis korelasi digunakan untuk mengetahui hubungan antara ukuran-ukuran tubuh terhadap bobot badan dengan alat bantu program SPSS 16, sementara kriteria nilai koefisien korelasi berdasarkan Victori et al. (2016).

\section{HASIL DAN PEMBAHASAN}

\section{Sifat kuantitatif}

Sifat kuantitatif ukuran tubuh kambing lokal di Pulau Moa disajikan dalam Tabel 2. Tampilan fenotip sifat kuantitatif ukuran tubuh kambing merupakan cerminan dari pertumbuhan dan menjadi ciri khusus suatu ternak. Menurut Mulliadi (1996) bahwa ukuran tubuh dengan komponen-komponen tubuh lain merupakan keseimbangan biologi sehingga dapat dijadikan untuk menduga gambaran bentuk tubuh dari suatu ciri spesifik bangsa ternak. Penampilan seekor ternak adalah hasil proses pertumbuhan dan adaptasi 
yang berlangsung dalam kehidupan ternak. Setiap bagian tubuh tersebut mempunyai kecepatan pertumbuhan atau perkembangan yang berbeda-beda.

Tabel 2. Rata-rata dan standar deviasi ukuran tubuh kambing lokal di Pulau Moa

\begin{tabular}{lccccc}
\hline \hline \multirow{2}{*}{ Ukuran tubuh } & \multicolumn{2}{c}{ Muda } & & \multicolumn{2}{c}{ Dewasa } \\
\cline { 2 - 3 } \cline { 5 - 6 } & Jantan $(\mathrm{n}=23)$ & Betina $(\mathrm{n}=25)$ & & Jantan $(\mathrm{n}=11)$ & Betina $(\mathrm{n}=23)$ \\
\hline Bobot badan $(\mathrm{kg})$ & $16,76 \pm 2,66$ & $12,90 \pm 3,90$ & & $43,08 \pm 3,25$ & $34,44 \pm 2,54$ \\
Panjang kepala $(\mathrm{cm})$ & $15,39 \pm 1,68$ & $12,87 \pm 2,33$ & & $28,83 \pm 3,08$ & $23,41 \pm 1,73$ \\
Lebar kepala $(\mathrm{cm})$ & $9,23 \pm 1,01$ & $7,22 \pm 1,40$ & & $18,15 \pm 1,94$ & $14,9 \pm 1,10$ \\
Tinggi kepala $(\mathrm{cm})$ & $7,91 \pm 0,87$ & $7,21 \pm 1,31$ & & $16,02 \pm 1,71$ & $12,77 \pm 0,94$ \\
Panjang telinga $(\mathrm{cm})$ & $17,59 \pm 1,92$ & $17,38 \pm 3,15$ & & $23,49 \pm 2,51$ & $18,09 \pm 1,33$ \\
Lebar telinga $(\mathrm{cm})$ & $8,24 \pm 0,90$ & $6,95 \pm 1,26$ & & $8,543 \pm 0,91$ & $7,44 \pm 0,55$ \\
Panjang badan $(\mathrm{cm})$ & $46,16 \pm 5,06$ & $41,20 \pm 7,46$ & & $80,09 \pm 8,55$ & $61,71 \pm 4,55$ \\
Lebar dada $(\mathrm{cm})$ & $10,99 \pm 1,02$ & $8,63 \pm 1,56$ & & $24,56 \pm 2,62$ & $20,21 \pm 1,49$ \\
Tinggi pundak $(\mathrm{cm})$ & $34,07 \pm 3,72$ & $29,61 \pm 5,36$ & & $79,02 \pm 8,44$ & $62,77 \pm 4,63$ \\
Dalam dada $(\mathrm{cm})$ & $18,68 \pm 2,04$ & $19,31 \pm 3,50$ & & $32,04 \pm 3,42$ & $25,53 \pm 1,88$ \\
Lingkar dada $(\mathrm{cm})$ & $45,06 \pm 4,93$ & $39,91 \pm 7,23$ & & $79,85 \pm 6,03$ & $63,84 \pm 4,71$ \\
Lingkar canon $(\mathrm{cm})$ & $6,59 \pm 0,72$ & $4,76 \pm 0,86$ & & $8,956 \pm 0,83$ & $8,16 \pm 0,65$ \\
\hline
\end{tabular}

Secara deskriptif, tampilan sifat kuantitatif pada kambing dalam kategori umur anak dan dewasa memiliki keragaman yang besar dan menjadi peluang untuk dilakukan seleksi demi mendapatkan bangsa unggul. Menurut Salamena et al. (2007) keragaman dalam suatu populasi penting untuk menentukan kebijakan pemuliaan pada wilayah dimana populasi berada. Selain itu, sifat kuantitatif kambing lokal di Pulau Moa khususnya kambing jantan memiliki ukuran tubuh lebih panjang dan bobot badan lebih besar dalam umur yang sama jika dibandingkan dengan kambing betina. Menurut Kumar et al. (2007) jenis kelamin merupakan faktor yang berpengaruh terhadap pertumbuhan kambing. Faruque et al. (2010) menyatakan pertumbuhan kambing jantan biasanya lebih cepat dari pada betina.

Bobot badan kambing lokal Moa jantan adalah 43,08 $\pm 3,25 \mathrm{~kg}$ dan betina 34,44 $\pm 2,54$ $\mathrm{kg}$. Berdasarkan potensi bobot badan, kambing lokal Moa merupakan tipe pedaging karena biasa dimanfaatkan dagingnya untuk konsumsi masyarakat. Kambing lokal Moa memiliki bobot badan lebih besar dibandingkan dengan kambing Kacang jantan yang memiliki bobot $25 \mathrm{~kg}$ serta betina $22 \mathrm{~kg}$ (Pamungkas et al. 2008) akan tetapi memiliki bobot badan lebih rendah dibandingkan dengan kambing Lakor, karena bobot badan kambing Lakor umur 1-3 tahun untuk jantan yaitu 59,17-80,59 kg dan untuk betina 34,43-46,64 kg (Siwa 2012).

\section{Sifat kualitatif}

Fenotipe sifat kualitatif meliputi warna bulu, garis muka, tanduk, bentuk telinga dan punggung kambing lokal di Pulau Moa disajikan dalam Tabel 3. Variasi warna bulu dengan persentase yang hampir merata yaitu warna hitam, putih, cokelat dan kombinasinya pada kambing lokal di Pulau Moa dikarenakan preferensi masyarakat dalam memelihara ternak tidak mengacu warna bulu. Hal tersebut diduga karena harga ternak tidak bergantung dengan warna bulu tertentu sehingga tidak ada seleksi dari masyarakat petani sebagai imbas dari kesukaan dalam memelihara ternak yang mengacu warna bulu tertentu. Variasi corak warna bulu kambing lokal di Pulau Moa memiliki kecenderungan sesuai 
dengan kambing Lakor. Menurut Siwa (2012) bahwa Kambing Lakor di Pulau Lakor Kabupaten MBD memiliki warna cokelat, putih, hitam dan kombinasinya. Gunawan et al. (2008) dan Hassen et al. (2012) menyatakan bahwa kecenderungan warna bulu menjadi faktor seleksi dalam pemeliharaan oleh peternak jika memiliki nilai pasar yang tinggi, kepercayaan masyarakat dan daya adaptasi yang baik terhadap lingkungan. Bentuk telinga kambing lokal Moa yang didominasi bentuk panjang dan terjuntai ke bawah. Ciri tersebut memiliki kemiripan dengan kambing Lakor di Pulau Lakor (Siwa 2012) meskipun masih diperlukan penelitian lebih lanjut untuk mengetahui hubungan kekerabatan antar bangsa kambing tersebut yang masih dalam satu kabupaten yang sama meskipun berada di pulau yang berbeda.

Tabel 3. Sifat kualitatif kambing lokal di Pulau Moa

\begin{tabular}{|c|c|c|}
\hline Sifat kualitatif & Jumlah (ekor) & Persentase $(\%)$ \\
\hline \multicolumn{3}{|l|}{ Pola warna bulu } \\
\hline Hitam & 6 & 7 \\
\hline Putih & 6 & 7 \\
\hline Cokelat & 6 & 7 \\
\hline Abu-abu & 6 & 7 \\
\hline Hitam dan putih & 9 & 11 \\
\hline Cokelat dan putih & 8 & 10 \\
\hline Cokelat dan hitam & 10 & 12 \\
\hline Cokelat muda & 7 & 9 \\
\hline Putih totol hitam & 9 & 11 \\
\hline Putih totol cokelat & 8 & 10 \\
\hline Cokelat hitam putih & 7 & 9 \\
\hline \multicolumn{3}{|l|}{ Profil garis muka } \\
\hline Cembung & 0 & 0 \\
\hline Datar & 82 & 100 \\
\hline \multicolumn{3}{|l|}{ Orientasi bentuk tanduk } \\
\hline Bertanduk & 34 & 41 \\
\hline Tak bertanduk & 30 & 37 \\
\hline Benjolan tanduk & 18 & 22 \\
\hline \multicolumn{3}{|l|}{ Bentuk telinga } \\
\hline Berdiri & 0 & 0 \\
\hline Setengah menjuntai & 44 & 54 \\
\hline Menjuntai ke bawah & 38 & 46 \\
\hline \multicolumn{3}{|l|}{ Bentuk garis punggung } \\
\hline Cembung & 2 & 2 \\
\hline Lurus & 33 & 41 \\
\hline Cekung & 47 & 57 \\
\hline
\end{tabular}

\section{Hubungan ukuran tubuh dengan bobot badan kambing}

Korelasi antara bobot badan dengan ukuran-ukuran tubuh (meliputi panjang badan, tinggi pundak, dalam dada dan lingkar dada) kambing lokal di Pulau Moa disajikan dalam Tabel 4. 
Tabel 4. Korelasi antara bobot badan dengan ukuran tubuh kambing lokal di Pulau Moa

\begin{tabular}{lcccc}
\hline \multirow{2}{*}{ Korelasi ukuran tubuh } & \multicolumn{2}{c}{ Muda } & \multicolumn{2}{c}{ Dewasa } \\
\cline { 2 - 5 } & Jantan & Betina & Jantan & Betina \\
\hline Bobot badan-panjang badan & 0,904 & 0,919 & 0,426 & 0,912 \\
Bobot badan-tinggi pundak & 0,903 & 0,920 & 0,227 & 0,829 \\
Bobot badan-dalam dada & 0,845 & 0,918 & 0,219 & 0,963 \\
Bobot badan-lingkar dada & 0,842 & 0,919 & 0,935 & 0,965 \\
\hline
\end{tabular}

Berdasarkan pengamatan diketahui bahwa ukuran tubuh kambing meliputi panjang badan, tinggi pundak, dalam dada dan lingkar dada memiliki hubungan erat terhadap bobot badan kambing (Tabel 4). Oseni \& Ajayi (2014) menyebutkan bahwa ukuran tubuh panjang badan, tinggi pundak, dalam dada dan lingkar dada merupakan prediktor yang baik untuk bobot badan. Trisnawanto et al. (2012) menyatakan bahwa nilai dari ukuranukuran tubuh semakin meningkat seiring dengan bertambahnya bobot badan ternak.

Korelasi bobot badan dengan lingkar dada memiliki nilai yang sangat tinggi pada semua jenis kelamin dan umur ternak. Hal tersebut dapat dipahami karena lingkar badan merupakan tempat melekat komponen tubuh seperti daging, lemak, organ dalam dimana memberikan bobot proporsi besar dalam bobot kambing. Faktor lain adalah pertumbuhan pada masa dewasa yang lebih mengarah ke otot dan lemak. Selain itu, korelasi bobot badan dan panjang badan memberikan juga nilai tinggi kecuali jantan dewasa yang memiliki nilai sedang. Korelasi bobot badan dan panjang badan yang menunjukkan nilai sedang pada jantan dewasa mengindikasikan lingkar dada lebih berperan dalam proporsi bobot tubuh sehingga memiliki nilai korelasi yang lebih baik dibandingkan dengan panjang badan. Hal tersebut sesuai dengan Ilham (2012) dan Victori et al. (2016) menyatakan lingkar dada memiliki hubungan yang sangat erat dengan bobot badan sehingga dapat digunakan untuk pendugaan yang paling mendekati untuk bobot badan kambing.

\section{KESIMPULAN}

Keragaman kambing lokal di Pulau Moa terlihat dari beberapa sifat kuantitatif berupa bobot badan, sejumlah ukuran morfometri dan sifat kualitatif berupa warna bulu, bentuk tanduk, telinga dan punggung. Pada sifat kualitatif bentuk muka adalah datar yang dapat menjadi ciri khusus. Keragaman pada sifat kuantitatif dan kualitatif kambing lokal di Pulau Moa membuka peluang untuk dilakukan seleksi demi memperoleh sifat dengan nilai ekonomis tinggi sebagai indikasi ternak yang unggul. Ukuran tubuh kambing terutama lingkar dada memiliki hubungan erat terhadap bobot badan kambing lokal di Pulau Moa. Mengingat bahwa kambing lokal juga terdapat di gugus Pulau Lemola (Leti, Moa dan Lakor) maka perlu dilakukan karakterisasi guna mengetahui hubungan kekerabatannya.

\section{DAFTAR PUSTAKA}

Adiati U, Priyanto D. 2011. Karakteristik morfologi kambing PE di dua lokasi sumber bibit. Dalam: Prasetyo LH, Damayanti R, Iskandar S, Herawati T, Priyanto D, Puastuti P, Anggraeni A, Tarigan S, Wardhana AH, Dharmayanti NLPI, penyunting. Teknologi Peternakan dan Veteriner untuk Peningkatan Produksi dan Antisipatif terhadap Dampak Perubahan Iklim. Prosiding Seminar Nasional Teknologi Peternakan dan Veteriner. Bogor, 78 Juni 2011. Bogor (Indonesia): Puslitbangnak. hlm. 472-478. 
BPS Kabupaten Maluku Barat Daya. 2016. Maluku Barat Daya dalam Angka 2015. Ambon (Indonesia): Badan Pusat Statistik Provinsi Maluku.

Eoh M. 2014. Kapasitas tampung dan komposisi zat-zat makanan padang penggembalaan ternak kerbau di Pulau Moa. Agrinimal. 4:77-82.

Faruque S, Chowdhury SA, Siddiquee NU, Afroz MA. 2010. Performance and genetic parameters of economically important traits of Black Bengal goat. J Bangladesh Agril Univ. 8:67-78.

Gunawan A, Jamal K, Sumantri C. 2008. Pendugaan bobot badan melalui analisis morfometrik dengan pendekatan regresi terbaik best-subset pada domba Garut tipe pedaging, tangkas dan persilangannya. Majalah Ilmu Peternakan. 11:1-6.

Hassen H, Baum M, Rischkowsky B, Tibbo M. 2012. Phenotypic characterization of Ethiopian Indigenous goat populations. Afr J Biotechnol. 11:13838-13846.

lham F. 2012. Karakteristik fenotipe sifat kualitatif dan kuantitatif kambing lokal di Kabupaten Bone Bolango. Laporan Penelitian. Gorontalo (Indonesia): Program Studi Peternakan Fakultas Pertanian. Universitas Negeri Gorontalo.

Kumar A, Singh U, Tomar A. 2007. Early growth paramether of Kutchi goats under organizae farm. India Vet J. 83:105-106.

Mulliadi D. 1996. Sifat fenotipe domba Priangan di Kabupaten Pandeglang dan Garut [Disertasi]. [Bogor (Indonesia)]: Institut Pertanian Bogor.

Nurfaizin, Matitaputty PR, Titahena MLJ, Yusuf. 2016. Pendampingan kawasan kambing di Maluku Barat Daya. Laporan Tahunan. Ambon (Indonesia): BPTP Maluku.

Oseni SO, Ajayi BA. 2014. Phenotypic characterization and strategies for genetic improvement of WAD goats under backyard systems. Open J Anim Sci. 4:253-262.

Pamungkas FA, BatubaraA, Dolokpasaribu M, Sihite E. 2008. Petunjuk teknis potensi plasma nutfah kambing lokal Indonesia. Bgoor (Indonesia): Puslitbangnak.

Salamena JF, Noor RR, Sumantri C, Inounu I. 2007. Hubungan genetik, ukuran populasi efektif dan laju silang dalam per generasi populasi domba di Pulau Kisar. J Indonesian Trop Anim Agric. 32:71-75.

Siwa IP. 2012. Kambing Lakor sebagai rumpun ternak asli Indonesia asal Maluku. Dalam: Prosiding Seminar Pengembangan Sumber Daya Genetik Rumpun Ternak Lokal dalam Mewujudkan Swasembada Daging dan Pangan Hewani yang ASUH di Maluku. Ambon, 20 September 2012. Ambon (Indonesia): Unpatti. hlm. 44-50.

Sulastri, Sumadi. 2005. Pendugaan umur berdasarkan kondisi gigi seri pada kambing Peranakan Ettawah di Unit Pelaksana Teknis Ternak Singosari, Malang, Jawa Timur. Majalah Ilmiah Peternakan. 8:1-10.

Thenu SFW. 2013. Model pengembangan agribisnis jagung untuk mendukung ketahanan pangan berbasis gugus pulau di Kabupaten Maluku Barat Daya Provinsi Maluku [Disertasi]. [Bogor (Indonesia)]: Institut Pertanian Bogor.

Trisnawanto, Adiwinarti R, DilagaWS. 2012. Hubungan antara ukuran-ukuran tubuh dengan bobot badan Dombos jantan. J Anim Agric. 1:653-668.

Victori A, Purbowati E, Lestari CMS. 2016. Hubungan antara ukuran-ukuran tubuh dengan bobot badan Kambing Peranakan Ettawah jantan di Kabupaten Klaten. J Ilmu-Ilmu Peternakan. 26:23-28.

Wahyuni V, Nafiu LO, Pagala MA. 2016. Karakteristik fenotipik sifat kualitatif dan kuantitatif kambing Kacang di Kabupaten Muna Barat. J Ilmu Teknologi Peternakan Tropis. 1:21-30. 